AUTORES

\section{Fabianne Manhães} Maciel*

fabiannemanhaes@

id.uff.br

\section{Lucas Pontes}

Ferreira**

Ic_pontes@hotmail. com

* Doutora em Direito. Professora adjunta da Universidade Federal Fluminense (UFF, Brasil).

** Mestrando pelo programa de pósgraduação em Direito Constitucional na UFF. Bolsista CAPES.

\section{Contramajoritarismo no caso da Lei da Ficha Limpa - LC n0 135/10}

\author{
Contramajoritarismo en el caso de la Ley de la Ficha Limpia - LC nº 135/10
}

Countermajoritarianism in the case of the Clean Sheet Act - LC n 135/10

\title{
RESUMO
}

O presente estudo visa examinar, por meio de abordagem descritiva e analítica, através do caso da lei da Ficha Limpa, a relação entre a jurisdição constitucional e a comunidade política na atual conjuntura democrática brasileira. Trata-se, a rigor, de uma problematização da efetivação da cidadania com interpretação jurisdicional da Constituição, no que diz respeito ao exercício contramajoritário do Supremo Tribunal Federal (STF). Para tanto, primeiramente, apresenta-se o julgamento da Lei Complementar $n^{\circ}$ 135/2010 colocando em evidência os principais pontos das discussões dos ministros, posteriormente, desenvolve-se alguns elementos da problemática da legitimidade do STF no que tange a interpretação constitucional construída democraticamente em conjunto com os cidadãos, podendo o STF exercer uma pedagogia constitucional.

\section{RESUMEN}

El presente estudio pretende examinar, a través de un enfoque descriptivo y analítico, a través del caso de la ley de la Ficha Limpa, la relación entre la jurisdicción constitucio-nal y la comunidad política en la actual coyuntura democrática brasileña. Se trata, en rigor, de problematizar la efectividad de la ciudadanía con una interpretación jurisdic-cional de la Constitución, en lo que se refiere al ejercicio contramayoritario del Supremo Tribunal Federal. Primero, se presenta el juicio de la Ley Complementaria $n^{\circ}$ 135/2010 poniendo en evidencia los principales puntos de las discusiones de los ministros, poste-riormente, se desarrollan algunos elementos de la problemática de la legitimidad del Su-premo Tribunal Federal en lo que se refiere a la interpretación constitucional construida democráticamente en conjunto con los ciudadanos, pudiendo el Supremo ejercer una pedagogía constitucional.

\section{ABSTRACT}

The present study aims to examine, in a descriptive and analytical approach, through the case of the Ficha Limpa Law, the relationship between the constitutional jurisdiction and

the political community in the current Brazilian democratic conjuncture. It is, strictly speaking, a problematization of the effectiveness of citizenship with judicial interpretation of the Constitution, in regard to the countermajoritarian exercise of the Federal Supreme Court. For this, firstly, the trial of Complementary Law 135/2010 is presented, highlighting the main points of the ministers ' discussions, and then some elements of the legitimacy of the Federal Supreme Court are developed, refers to the constitutional interpretation democratically constructed in conjunction with citizens, the Supreme being able to exercise a constitutional pedagogy. 
Entre as diversas causas que chegaram ao Supremo Tribunal Federal (STF), algumas trouxeram à luz a discussão acerca de seu papel contramajoritário. Sabe-se que política majoritária é, a rigor, aquela firmada na seara dos poderes Legislativo e Executivo, cuja realização ocorre através dos votos computados da maioria dos cidadãos. Logo, o atuar contramajoritário do Judiciário, seria, sumariamente, julgar as causas em observância aos direitos fundamentais da minoria, que correm o risco de serem eliminados pela vontade duma denominada maioria, expressa, por exemplo, na opinião pública.

Não obstante tais casos, passa-se a análise do julgamento que se deu em conjunto das Ações Direta de Constitucionalidade $n^{\circ} 29$, 30 e Ação Direta de Inconstitucionalide (ADI) n 4578, que discutiam a possibilidade de aplicação da lei "Ficha Limpa" nas eleições de 2010. Para tanto, primeiramente, apresenta-se o julgamento da Lei Complementar no 135/2010 colocando em evidência os principais pontos das discussões dos ministros, posteriormente, desenvolve-se alguns elementos da problemática da legitimidade do STF no que tange a interpretação constitucional construída democraticamente em conjunto com os cidadãos, podendo o STF exercer uma pedagogia constitucional.

\section{Julgamento da lei Ficha Limpa - LC nº 135/2010}

No julgamento em conjunto das ações declaratórias de constitucionalidade ( $n^{\circ} 29$ e 30) e ADI $n^{\circ} 4578$, os ministros do STF, em sua maioria, declararam a Lei Complementar $n^{\circ} 135 / 2010$ constitucional. Essa lei, que teve origem num projeto de iniciativa popular, trouxe outras hipóteses de inelegibilidade, que tinham como escopo proteger a probidade e moralidade administrativas no exercício do mandato. Isto é, alterou-se a Lei Complementar nº 64 de 1990, sobretudo no seu artigo $1^{\circ}$.

Entretanto, a Confederação Nacional das Profissões Liberais (CNPL), por entender que a alteração dada pela lei à alínea " $\mathrm{m}$ " do artigo 10, sofria de "inconstitucionalidade chapada", arguiu a sua inconstitucionalidade. Para a entidade, é inconcebível tornar inelegível por oito anos quem for excluído do exercício da profissão, por decisão do órgão profissional competente, em decorrência de infração ético-profissional. De outro lado, o Partido Popular Socialista (PPS) e a Ordem dos Advogados do Brasil (OAB), pleiteavam a constitucionalidade da lei, pedindo, inclusive, que seus efeitos retroagissem a fatos anteriores a vigência da norma. Sob este ponto, veio à luz a discussão acerca do princípio da anterioridade eleitoral como garantia constitucional, previsto no artigo 16 da Constituição da República Federativa Brasileira de 1988 (CRFB/88).

De acordo com os que queriam que os efeitos retroagissem, melhor seria que se impugnassem as candidaturas anteriores à eleição de 2012, para que aos candidatos a que venha a ser negado o direito de se elegerem no ano de vigência da lei, não questionem sobre a constitucionalidade da aplicação das hipóteses de inelegibilidade a atos anteriores à edição da norma. Contudo, ficou consolidado o entendimento no STF de que os fatos anteriores à lei atentadores à moralidade e a probidade são passíveis de observância à norma. Não se considerou legítima a expectativa à elegibilidade do indivíduo enquadrado nas hipóteses legais de inelegibilidade, condenado em segunda instância ou por colegiado no exercício da competência de foro por prerrogativa de função, da rejeição das contas públicas, da perda de cargo público ou do impedimento do exercício de profissão por violação do dever ético-profissional.

Entendeu-se que a LC no 135/10 atende ao princípio da proporcionalidade, haja vista que condiz com os objetivos moralizadores pretendidos, estabelece requisitos qualificados de inelegibilidade 
e impõe sacrifício à liberdade individual de candidatar-se a cargo público eletivo que não supera os benefícios socialmente desejados em termos de moralidade e probidade para o exercício do cargo eletivo.

Ainda, de acordo com o STF, a lei não fere o núcleo essencial dos direitos políticos, na medida em que estabelece restrições temporárias aos direitos políticos passivos, sem prejuízo das situações políticas ativas e, além disso, as hipóteses de inelegibilidade não se aplicam às eleições de 2010 e anteriores, bem como para os mandatos em curso. A LC n 135/10, em seu artigo 26-C dispõe que "o órgão colegiado do tribunal ao qual couber a apreciação do recuso (...) poderá, em caráter cautelar, suspender a inelegibilidade (...)". Sob este ponto, deu-se início na sessão de julgamento ao debate dos ministros acerca desse "órgão colegiado", pois, há um precedente no Tribunal Superior Eleitoral (TSE) de que órgão colegiado seria o júri - que não é órgão de segundo grau. Em relação a esse precedente, esclareceu-se que as decisões do júri são colegiadas e devido a sua natureza de não poderem ser alteradas, senão por recurso, deu-se esse entendimento de órgão colegiado. Nessa medida, o citado artigo, "afasta eventual subjetividade de um Relator individual" para conceder cautelar, conforme palavras do ministro Ricardo Lewandowski.

No curso do julgamento, recordou-se o princípio da presunção de inocência, ao qual o ministro Luiz Fux defendeu que não poderia o STF ir contra ao que entende a população sobre tal princípio bem como sobre quem pode exercer um mandato eletivo. Assim, verbalizou:

O Supremo Tribunal Federal pode ser contramajoritário quando decide contra a maioria parlamentar, quando decide direitos da minoria previstos na Constituição. O Supremo Tribunal não é contramajoritário para ir contra a opinião da população, sobre o que ela entende a respeito da presunção de inocência ou sobre quem pode exercer um mandato político. Evidentemente ela não nos pauta, mas temos que ouvi-la porque todo poder emana do povo e em seu nome é exercido (ADI 4578. Brasília. Relator: Ministro Luiz Fux. Publicação: DJ 29.06.2012, pp. 5-6).
Em entrevista ao jornal Valor Econômico (Basile, 2011), o ministro Luiz Fux declarou que não se sentiu incomodado ao votar contra a aplicação da Lei Complementar para as eleições de 2010, porque seguiu a Constituição, a qual é a vontade do povo, na sua concepção. Disse que para os passos seguintes do julgamento da ação, o STF teria de verificar onde está a soberania popular: "em milhões de pessoas que deixaram as suas assinaturas para a aprovação da lei ou nos milhões de votos que elegeram políticos com 'ficha suja' para o Congresso". Sobre esse julgamento, analisa Georges Abboud, o fato de a lei autorizar que seja, em última instância, promovida a cassação dos políticos a serem eleitos pelo voto popular, já caracterizaria o papel contramajoritário do Supremo (Abboud, 2012, p. 7). Caso se devesse observar a vontade da maioria para promover a cassação, estar-se-ia diante duma grande contradição.

\subsection{Principais pontos a respeito dos votos dos ministros}

Na ADI no 4578/DF, o ministro Luiz Fux ao proferir o seu voto criticou o atuar contramajoritário do STF, na medida em que as decisões do Supremo estavam sendo alvo de críticas pela sociedade civil. Para o ministro, a discussão do tema vem desde a Arguição de Descumprimento de Preceito Fundamental (ADPF) no 144 em que cidadãos organizados debatiam o entendimento jurisprudencial do TSE, segundo o qual apenas a condenação definitiva poderia ensejar inelegibilidade. Fato este que fez a legitimada ativa - Associação dos Magistrados Brasileiros (AMB), divulgar as chamadas "fichas sujas". Além disso, diante da manifestação do STF de que as hipóteses de inelegibilidade só poderiam ser criadas por Lei Complementar, tevese a organização por parte da sociedade para apresentação do Projeto de Lei Complementar no 518/09. Posteriormente, no Recurso Extraordinário 633.703 (relator ministro Gilmar Mendes), afastouse a aplicabilidade das hipóteses de inelegibilidade às eleições de 2010, fato que ensejou as ações da "Ficha Limpa". Diante disso, o ministro Fux ressalta que esse atuar contramajoritário do STF não poderia ir contra opinião popular acerca da aplicação do princípio da presunção de inocência, ora afastado para questões eleitorais, devendo, portanto, a Corte rever tal posicionamento tendo em vista o clamor social. 
Além disso, versa que por ser ramo diverso do direito Penal e Processual Penal, tal princípio não deveria se ater a literalidade, podendo ser relativizado, já que se trata de matéria relacionada ao direito eleitoral:

Não cabe discutir, nestas ações, o sentido e o alcance da presunção constitucional de inocência (ou a não culpabilidade, como se preferir) no que diz respeito à esfera penal e processual penal. Cuida-se aqui tão somente da aplicabilidade da presunção de inocência especificamente para fins eleitorais, ou seja, da sua irradiação para ramo do Direito diverso daquele a que se refere a literalidade do art. 5, LVII, da Constituição de 1988 (ADI 4578. Brasília. Relator: Ministro Luiz Fux. Publicação: DJ 29.06.2012, p. 9).

Ofundamento desse entendimento do ministro tem forte influência da "crise do sistema representativo brasileiro e o anseio da população pela moralização do exercício dos mandatos eletivos no país" e no "fenômeno da judicialização da política, que certamente decorre do reconhecimento da independência do Poder Judiciário no Brasil, mas também é resultado da desilusão com a política majoritária" (grifo do autor) (ADI 4578/DF, p. 10). Logo, por essa sensibilidade cívica, de acordo com o que dispõe o ministro, seria possível se esquecer do dever de coerência entre os diplomas legais, já que a literalidade dos dispositivos e princípios ficaria adstrita somente a cada área especializada do saber jurídico. Mais crítico ainda se configura esse cenário quando se verifica que para o Ministro Fux, "ou bem se realinha a interpretação da presunção de inocência, ao menos em termos de Direito Eleitoral, com o estado espiritual do povo brasileiro, ou se desacredita a Constituição" (ADI 4578/ DF, p. 12). Quer dizer, troca-se a força normativa da Constituição pela vontade do povo, o que é claramente combatido por Konrad Hesse (1991). A Constituição deve ter um mínimo normativo que precisa ser assegurado pela jurisdição constitucional para que não deixe de significar a ordem jurídica fundamental. Em outras palavras, que não deixe de ser jurídica para ser meramente política. Do contrário, bastaria organizar-se coletivamente, apresentar a insatisfação sobre determinado assunto político ao STF, que este faria uma espécie de ponderação entre a Constituição e os anseios sociais, para ter um resultado. Espécie de: dê-me a insatisfação que a acolho independente do texto constitucional, e dou-lhe o direito. E, assim, constrói-se o constitucionalismo do Brasil:

Obviamente, o Supremo Tribunal Federal não pode renunciar à sua condição de instância contramajoritária de proteção dos direitos fundamentais e do regime democrático. No entanto, a própria legitimidade democrática da Constituição e da jurisdição constitucional depende, em alguma medida, de sua responsividade à opinião popular (ADI 4578. Brasília. Relator: Ministro Luiz Fux. Publicação: DJ 29.06.2012, p. 14).

Em seu extenso trabalho sobre a influência da opinião pública no comportamento dos membros do STF, Marcelo Novelino (2013, p. 307), identificou a hipótese de quanto maior "o prestígio institucional da Corte, maior a probabilidade desta adotar uma postura mais ativista". No que tange ao Supremo, verificou que os ministros do STF tendem a ter maior sintonia com as "preferências políticas da elite intelectual e econômica do que com o público em geral" (Novelino, 2013, p. 308). Uma vez que normalmente os ministros são oriundos desse meio, onde o corpo profissional reforça o diálogo e relações com pessoas da área jurídica. Isso somase à problemática de como se dimensionar a que maioria a decisão judicial irá satisfazer, haja vista o caráter difuso do que vem ser opinião popular. Seria a mídia? Ibope? Censo? Audiência da TV Justiça? Os postulantes da ação constitucional? O quantitativo de votos dos cidadãos?

Evidentemente, nada disso corresponde a hermenêutica constitucional, pois a interpretação nesse particular vem de qualquer lugar, menos do texto constitucional, no qual a presunção de inocência disposta no art. 50, LVII, da CRFB/88 é inequívoca, quanto a não restringir à área do direito e a relativizar os sujeitos: "ninguém será considerado culpado até o trânsito em julgado de sentença penal condenatória". A ministra Rosa Weber, percorre caminhos semelhantes ao do ministro Fux:

Certamente, sendo esta Corte uma instituição contramajoritária, seus julgamentos não se vinculam às aspirações da maioria. 
Mas igualmente não deve ser o Supremo Tribunal Federal insensível a elas, já que, em uma democracia pluralista, todos compõem a sociedade aberta dos intérpretes da Constituição, e diferentes pontos de vista devem ser levados em consideração para se alcançar a melhor interpretação possível do texto constitucional. (...). Se no próprio processo penal, onde está em jogo a liberdade de ir e vir, admite-se que sejam estabelecidas restrições ao princípio da presunção de inocência, como a imposição, antes do julgamento, de prisão provisória, não me parece, data vênia, correto concluir que, em outros ramos do Direito, seria vedado em absoluto também estabelecer restrições a direitos de outra natureza antes de um julgamento (ADI 4578. Brasília. Relator: Ministro Luiz Fux. Publicação: DJ 29.06.2012, p. 11).

Com efeito, "todos que compõem a sociedade aberta pluralista dos intérpretes da Constituição" participam do processo de intepretação, entretanto, o próprio Peter Häberle (2002, p. 46), autor dessa teoria pluralista, destacou o dever da Corte Constitucional de levar em conta aqueles que não participam do processo interpretativo, isto é, as minorias, para terem os seus direitos fundamentais resguardados, que ao caso o réu não poderia ter sua esfera jurídica restringida.

Doutra sorte, os ministros Joaquim Barbosa e Ricardo Lewandowski também entendem pela constitucionalidade fundamentando na supremacia do interesse público sobre o particular. Entretanto, George Abboud já desmitificou essa ideia de que o interesse público se sobrepõe ao particular, nos seus termos:

o erro nasce, justamente, da ignorância do fato de que os direitos fundamentais são constitutivos, tanto do indivíduo como da comunidade. Portanto, são constituídos não apenas em favor do indivíduo, porquanto cumprem uma função social e compõem o fundamento funcional da democracia. (...) nos direitos fundamentais estão fundidos interesses públicos e privados, disso retémse que, tão logo um direito fundamental for lesionado, sempre será afetado o interesse público (Abboud, 2016, pp. 454 - 455).
Apesar de a decisão ter sido declarada constitucional (procedente) por maioria dos votos, entre os vencidos, destaca-se o voto do ministro Gilmar Mendes:

O argumento de que a lei é de iniciativa popular não tem peso suficiente para minimizar ou restringir o papel contramajoritário da Jurisdição Constitucional. É compreensível a ação das várias associações e das várias organizações sociais tendo em vista a repercussão que esse tema da "ficha limpa" tem na opinião pública. Sabemos que, para temas complexos em geral, há sempre uma solução simples e em geral errada. E para esse caso a população passa a acreditar que a solução para a improbidade administrativa, para as mazelas da vida política, é a Lei da Ficha Limpa. A partir daí há, na verdade, a tentativa de aprisionar, o que nos dificulta enormemente a missão nesta Corte, como em outros casos, porque acabamos tendo de nos pronunciar de forma contramajoritária, claro, tendo em vista a opinião pública, segundo as pesquisas manifestadas de opinião. Mas a missão desta Corte é aplicar a Constituição, ainda que contra a opinião majoritária. Esse é o ethos de uma Corte Constitucional. É fundamental que tenhamos essa visão. (...). Ademais, é sempre importante lembrar que permanecem no sistema outros mecanismos, postos à disposição dos cidadãos e dos diversos grupos sociais, para impedir a candidatura e a consequente eleição de pessoas inaptas, do ponto de vista da probidade administrativa e da moralidade, para o exercício do mandato eletivo. (...). Uma das características fundamentais de um regime democrático é a existência de múltiplos meios de impedir a chegada ou a permanência do mau governante no poder. (...). O primeiro e mais elementar mecanismo de controle é o voto. (...). Outro mecanismo de controle é a escolha de candidatos no âmbito interno dos próprios partidos políticos. Cabe às agremiações 
políticas a eleição de candidatos cuja vida pregressa os qualifiquem para exercer, com probidade e moralidade, determinada função pública (grifos do autor; ADI 4578. Brasília. Relator: Ministro Luiz Fux. Publicação: DJ 29.06.2012, p. 18).

Nesse sentido, controle de constitucionalidade serve, justamente, para frear determinados impulsos sociais, e garantir que o poder constituinte originário mantenha suas forças. Atuar contramajoritariamente nos casos de violação da Constituição, e consequentemente de direitos e garantias individuais, significa, reforçar a necessidade da organização social e garantir a guarda da Constituição, ao invés de se alimentar um status representacional jurídico.

Conforme a teoria do discurso (Habermas, 2011; 2012), a legitimação das normas vem do espaço público de discussão, respeitado os processos e pressupostos comunicacionais necessários à formação discursiva da opinião e da vontade, a fim de se possibilitar o exercício da autonomia política e a criação legítima do direito, de modo racional. Dessa forma, o Judiciário tomando para si esse procedimento, estaria, em dada medida, obstruindo a mobilização do direito, nos termos do paradigma procedimentalista. Porque desvirtua o fomento de outros mecanismos de articulação na esfera pública, criados ou desenvolvidos pelos indivíduos através de suas insurgências.

De acordo com a argumentação do ministro Mendes em seu voto, na questão da "ficha limpa", quando o STF "aplica rigorosamente a Constituição poderá desencadear um frutífero diálogo institucional entre os poderes e um debate público participativo em torno dos temas nela versados" (ADI 4578/DF, p. 21). Ou seja, no momento em que os ministros adotam o texto constitucional como parâmetro de compreensão fazendo com que dele advenha interpretação clarificada na norma, posto que seu produto, possibilita dois desdobramentos: o primeiro diz respeito ao fato de se atribuir funcionamento constitucionalmente adequado à jurisdição, e, por conseguinte, ativar os mecanismos dispostos na Carta da República para atingir o fim pretendido, que ao caso é resolver a improbidade administrativa dos candidatos inaptos.
Um dos mecanismos é o voto, consoante o ministro Gilmar Mendes, uma vez que a educação política não vem de uma decisão judicial, simplesmente. Vem do aprendizado no campo social, com os debates de ideias, campanha, manifestações, por exemplo. Por essa razão o STF não tem de fazer malabarismos interpretativos, para fazer com que um princípio fundamental como o da presunção de inocência tenha por fundamento a opinião pública. Porque se assim for, "se tudo o que não está previsto na Constituição pode ser 'realizado' pelo Poder Judiciário, não precisaríamos sequer ter feito a Constituição: o judiciário faria melhor (ou o Ministério Público)" (Streck, 2009, p. 14, grifos do autor).

É fora de dúvida que não se pode descurar a tensão existente entre jurisdição constitucional e democracia. O primeiro entendido como limitação do governo por meio da Constituição e o segundo compreendido na soberania do povo. Porém, é preciso ter em consideração que o Judiciário tem de atuar dentro das possibilidades e dos limites abertos pelo ordenamento jurídico, e não nos limites subjetivos da consciência dos magistrados ou na promoção da vontade geral da população. Até mesmo porque, não há elemento condizente com o princípio constitucional democrático para se avaliar como a Corte sistematizaria suas decisões levando em conta, puro e simplesmente, a vontade da maioria.

Destarte, nas linhas do debate do ministro Gilmar Mendes, não se pode perder de vista que "o modelo contramajoritário pretende proteger o indivíduo contra si mesmo, muitas vezes" (ADI 4578/DF, p. 7) e, até a própria democracia. Ao STF é preciso ser resguardado esse poder de contrariar a vontade da maioria, para que se possa garantir a supremacia do Texto Constitucional, e este ative o exercício da democracia através do e no direito, bem como assegure a preservação dos direitos fundamentais do cidadão e das minorias.

\section{O STF e o folhetim}

Embora seja usualmente comum no Brasil a denominação de Corte constitucional como 
sinônimo para fazer referência ao STF, no sentido verdadeiro, ambos estão mais para antônimos. Abboud, na vertente de Nelson Nery Junior, versa que a composição do Supremo é um dos fatores que causa sério problema de legitimidade. Para tanto, lança três hipóteses como solução, via emenda constitucional: "1) a retirada do STF do organograma do Judiciário, de modo a tornálo um órgão suprapoderes; 2) aumento de representatividade na sua composição mediante indicação por parte dos demais poderes, e não apenas por parte do Executivo" e, por fim, a terceira, "a criação de mandatos para o exercício do cargo de Ministros do STF, em substituição ao atual regime de vitaliciedade" (2016, p. 147).

Esse modelo proposto pelo professor paulista, busca equiparar o STF à composição dos legítimos tribunais constitucionais, situando-o no organograma do Estado, e não mais no Poder Judiciário, tal como é no Brasil, que exerce função de órgão de cúpula, a mais alta instância do país. Isso, em razão dos excessos de poder que o torna único, como, por exemplo, "possibilidade de julgar com efeito vinculante a ação declaratória de constitucionalidade e proferir súmulas vinculantes" (Abboud, 2016, p. 147).

As imperfeições da composição do STF também foram objeto de críticas de Dalmo Dallari (2007), para quem a exagerada gama de competência que Ihe foi conferida (prestação da jurisdição ordinária e constitucional) constitui problema"por culpa dele próprio que interpretou 'mais competência' como sinônimo de 'maior autoridade'". Dallari aponta também outros fatores que sobrecarregam o STF como o "excesso de processualismo que caracteriza o sistema brasileiro" que ajuda a aumentar o número de recursos aos tribunais superiores e, somado a isso, o fato das autoridades brasileiras "respeitarem pouco a Constituição e as leis, ensejando maior número de ações judiciais contra órgãos públicos" (Dallari, 2007, p. 115).

Como possíveis soluções a essas questões, Dallari acredita que duas evitariam a sobrecarga do Supremo: "aumentar o número de juízes ou reduzir as competências do tribunal" (2007, p. 114). Porém, não deixa de destacar os benefícios que se teria ao caso do STF exercer apenas o controle de constitucionalidade das leis, pois se reduziria as pautas e "poderia com rapidez e eficiência atuar como verdadeiro guarda da Constituição, impedindo a vigência de leis e atos inconstitucionais e responsabilizando os agressores da normalidade constitucional" (Dallari, 2007, p. 114). Pelo seu entendimento, é de suma importância que se atribua verdadeiro caráter de Tribunal Constitucional para que a Constituição brasileira seja "efetivamente vigente e respeitada, o que contribuiria para a estabilidade política e a superação das injustiças sociais" (Dallari, 2007, p. 114).

Essa reflexão sobre o aspecto institucional do STF evidencia a necessidade de se refletir e repensar não só a sua composição orgânica, mas, sobretudo, os riscos oferecidos à cidadania e ao próprio Estado Democrático de Direito ante o discurso de carência representacional por parte da sociedade brasileira na contemporaneidade.

A relativização da atuação contramajoritária, aumenta a discussão a respeito dos limites de atuação dos ministros, no que se relaciona a jurisdição constitucional, e da legitimidade a eles conferida para agirem como se representantes do povo fossem. Sob cariz do "importante papel democrático da jurisdição constitucional" (Barroso, 2015, p.43), o ministro Luís Roberto Barroso, defende que determinadas decisões em virtude do avanço social que podem provocar, o STF não pode se fazer de rogado. Isso ficou configurado nos votos das ações anteriormente analisadas, mais precisamente da Ação Direta de Constitucionalide n²9, em que se viu a relutante e vencedora discussão de se interpretar o princípio da presunção de inocência de acordo com o que a maioria da população queria, como se a Constituição não fosse clara na determinação desse princípio como fundamental e o STF não tivesse a função de atribuir coerência aos códigos. Também na Arguição de Descumprimento de Preceito Fundamental (ADPF) n 132, prevaleceu o interesse da maioria em possibilitar que o programa normativo ordinário alterasse o texto constitucional. Diz-se que isso é prejudicial à cidadania e, por conseguinte, à democracia, porque essa dependência do Judiciário por parte da população pode fazer (está fazendo) dele um promotor social, e, com isso, "corre-se o risco de 'criar' cidadãos de segunda classe, que, em vez de reivindicarem seus direitos no campo da política, 
apostam no paternalismo juridicista" (Streck, 2014, p. 65).

A crescente confiança no STF para resolver as pautas sociais ignora o fato de que não existe nenhuma outra instituição acima dele, que possa barra-lo. Faz-se preciso que esse Poder não se equivalha da autonomia e independência funcional (art. $2^{\circ}$, da CRFB/88) para utilizar os meios que lhes são próprios de produção e reprodução do direito de forma autorreferenciada no sentido de Luhmann (Amado, 2004), porque a interpretação corre o risco de passar a ser apenas aquilo que o STF entende. No mesmo sentido, analisando o contexto estrangeiro da Alemanha, Ingeborg Maus destaca: "assediado ilimitadamente pelas oposições do momento, e em especial sobrecarregado de queixas constitucionais (Verfassungsbeschwerde), o TFC procede à sua auto-reprodução e gerencia uma 'mais-valia' que de longe supera suas vastas competências constitucionais" (Maus, 2000, p. 191).

Maus complementa seu estudo constatando que a competência do TFC (Bundesverfassungsgericht) passou a derivar, não mais da Constituição, e sim dos "princípios de direito suprapositivos que o Tribunal desenvolveu em sua atividade constitucional de controle normativo" (Maus, 2000, p. 191-192). Com isso, o que ocorreu foi que as outras instâncias políticas foram submetidas à Constituição, ao passo que o Tribunal restou desvinculado das regras constitucionais. Nessa vertente, "por conta de seus métodos específicos de interpretação constitucional, atua o TFC menos como 'Guardião da Constituição' do que como garantidor da própria história jurisprudencial, à qual se refere legitimamente de modo auto-referencial" (Maus, 2000, pp. 191-192).

Em tal perspectiva, voltando ao cenário brasileiro, o atuar representativo do STF permite sua analogia à mulher do Folhetim de Chico Buarque (1977 - 1978), que só diz sim aos homens, faz suas vontades, mas no outro dia, nenhum deles a interessa mais, porque ela é determinada, dona de si e esses momentos de prazer servem apenas para satisfazer sua autonomia, haja vista que o seu eu-lírico é tão independente que não precisa se vincular a homem algum. Em analogia aos personagens da canção, o folhetim, dado o caráter transitório, seria a maioria popular a qual basta se apresentar como maioria traduzindo o clamor social da opinião pública, dizendo suas meias verdades de que o Congresso não tem condições políticas para resolver a demanda pleiteada, que o STF diz sim. Mas, na manhã seguinte à sentença, o que fica não é o exercício da cidadania, a conquista democrática (que foi mitigada), mas sim o agigantamento da esfera de atuação do Judiciário. Já que o que está se configurando é o que a maioria quer e o judiciário diz que é.

Se "ser cidadão é ter a possibilidade de se associar realmente à gestão da vida pública" (Garapon, 2001, p. 201), é no mínimo inteligível que esta não se resume ao campo do judiciário. Aliás, de acordo com Garapon (2001, p. 26 - 28) a desenfreada confiança nos Tribunais, vem justamente de uma crise no funcionamento das instituições políticas e da própria sociedade que não consegue articular meios para se organizar coletivamente. Então, adota como saída para resolução de problemas de diversas ordens a crença na figura do juiz como o "guardião das promessas democráticas". Porém, o exercício da cidadania não ocorre tão somente nos espaços mudos dos modernos edifícios da justiça (Garapon, 2001, p. 193). Pouco adianta a Corte promover, de forma incompatível com o texto constitucional, o que o Executivo e o Legislativo não fazem, já que falta aos indivíduos meios cognitivamente abertos ao fomento às suas articulações no âmbito civil. No caso do direito eleitoral, votam e voltam para casa. Em relação ao direito de se manifestar, vão às ruas e voltam para casa, as jornadas de junho de 2013 são exemplo (Garschagen, 2015). Pouco se conhece de pautas que canalizem a participação dos cidadãos de modo a possibilitar a criação de instituições civis que sirvam como espaço no qual possa ocorrer uma luta democrática com a contribuição de cada sujeito.

Urge a insurgência de instâncias que fomentem a participação e convergência das forças populares na esfera pública, nos outros âmbitos institucionais do Estado. Para solucionar essa problemática é preciso que se remodele a participação cidadã a partir da Constituição, isto é, que "o agir público/ privado se oriente pela prescrição da Constituição" (Ribeiro, 2015, p. 2167).

Porque do contrário, considerando o atual contexto em que cada vez mais a sociedade reclama por 
maior efetividade do Direito Penal com a atribuição de penas mais severas, questionável também pode ser a relativização da pena de morte, a qual só é permitida em caso de guerra declarada (art. 50, XLVII, "a", da CRFB/88). Já que é facultado em caso de guerra, na hipótese de haver forte opinião pública favorável à instituição aos casos de crime hediondo, poderia o STF declarar uma demanda processual deste teor constitucional? Nas linhas do professor Abboud:

Mesmo que grande parte da sociedade e a maioria parlamentar entendam que a pena de morte consiste em alternativa viável para a diminuição da criminalidade, essa vontade, apesar de ser da maioria política, não poderá prevalecer, porque os direitos fundamentais (no caso, a vida) a impedem de e concretizar. Qualquer lei ou emenda constitucional que pretenda instituir a pena de morte diante de nosso sistema constitucional será considerada inconstitucional e não poderá gerar efeitos (Abboud, 2016, p. 116).

Quer dizer, há um teto constitucional a ser respeitado e fundamentado. Por isso, se aponta como hipótese de solução a essa apropriação dos interesses sociais por parte do Judiciário a atuação nos termos da Crítica Hermenêutica do Direito (CHD), cuja fundamentação jurídica não contará com a independência cognoscitiva do magistrado, mas sim com a interpretação justificada consoante os métodos interpretativos do ordenamento jurídico constitucional. A consequência disso é que essa decisão poderá ser questionada à luz do texto constitucional, porque um dos pressupostos dessa hermenêutica é o de que a lei não vincula apenas os seus destinatários, mas também os seus intérpretes, que pela concepção de Häberle (2002) são todos os indivíduos. Assim, o STF não poderá deteriorar os limites da competência constitucional. Desse modo, a importância da abordagem do método procedimentalista de democracia está no fato de que essa concepção:

exige que o juiz preencha um papel reflexivo e não mais dedutível para que as partes sejam exigidas a definir - e respeitar - elas mesmas sua própria regra moral. Os interesses da justiça não são mais, como antigamente, garantidos pelo juiz através da simples intermediação de uma regra de direito, mas sim mantendo com a realidade apresentada uma relação nova, mais concreta e preocupada com certos princípios. O juiz deve dar um sentido concreto aos princípios em cada situação. A norma não tem mais conteúdo geral e universal deduzido a priori, cabendo ao juiz atualizar e contextualizar seu espírito, incessantemente. Portanto, não se trata da capitulação da justiça, mas, pelo contrário, de sua preocupação em assumir a perda de critérios substanciais da justiça almejada pela democracia (Garapon, 2001, p. 238, grifos do autor).

Dito em outras palavras, a norma é construída a partir da problemática com o texto, sendo a exposição da interpretação deste. Cada situação jurídica terá uma norma, por isso cada decisão deve ser justificada, fundamentada (art. 93, IX da CRFB/88). Justamente porque a sentença não é a cidadania. A sentença é um processo integrante dela, porque cidadania requer construção diária. Nesse diapasão, a Constituição funcionará como verdadeiro poder de ação, uma vez que os sujeitos a partir da sua condição de ser no Estado constitucional, poderão atuar como seus legítimos intérpretes, e ela será a responsável por reordenar a disritmia cidadã. É momento, portanto, do STF se conter em exercer jurisdição constitucional (que não pressupõe a sociedade fora do processo decisório), para possibilitar que através do exercício cidadão a democracia possa avançar conforme a compreensão constitucional para que os próprios sujeitos (como intérpretes) organizem suas pautas com animus de efetivá-la.

Em sintonia com o sentido procedimentalista de Antoine Garapon (2001, p. 172), não se trata opor a justiça à democracia, mas que esta possa se dinamizar por aquela. Para Garapon, "a justiça deve incumbir-se de refortalecer o poder. Ao juiz é atribuída a função de legitimar a ação política, estruturar o sujeito, organizar os laços sociais, dispor as construções simbólicas, certificar a verdade" (2001, p. 177). Ainda de acordo com o jurista francês, para a estruturação de uma democracia renovada, "o espaço judiciário não deve hesitar em estabelecer sua diferença e saber guardar suas distâncias, correndo o risco de deixar frustrados os fiscais em que todos nós nos convertemos" (Garapon, 2001, p. 189). 
Para tanto, de acordo com todo desenvolvido, entende-se que num primeiro momento o Judiciário representado peloSTF se equivalendo dos métodos hermenêuticos comprometidos com a força vinculante constitucional, que não se confunde com uma atuação representacional, mas de guarda da Constituição e, por conseguinte, da soberania popular, inibiria o excessivo deslocamento de questões de cunho político e social que podem ser resolvidas por outros mecanismos, como, por exemplo, processo administrativo para regular a ação das autoridades do Executivo.

Isso fomenta a insurgência cidadã e, principalmente, contribui para que haja a formação de uma consciência coletiva, porque no âmbito das relações sociais será dado espaço para que o problema ocorra, os sujeitos o identifiquem, e a partir disso possam se mobilizar para resolvê-lo. É preciso tornar mais claro o entendimento de que não se quer dizer que o STF deixe de atender as demandas sociais, muito pelo contrário. Tem de atender, pois constitui um dever de jurisdição. A questão é que não lhe cabe assumir a retórica de promotor social para fazer encaixes hermenêuticos, desrespeitando a própria Constituição, como se verificou na análise dos casos. Quando o judiciário não acolhe uma demanda por respeitar os direitos fundamentais, seja da maioria ou minoria da sociedade, às cláusulas pétreas, a essência normativa constitucional, atua como firme barreira aos devaneios (anti)democráticos. Conforme, Daniel Sarmento:

a importância disso está no fato de que esse atuar garantirá a lei cujo conteúdo normativo esteja conforme à Constituição Federal, não se podendo mais argumentar com sua autoridade como decorrente da vontade de maiorias governamentais ou parlamentares que, antes de tudo, devem pautar suas condutas pela supremacia da Constituição, submetida esta à incontestável interpretação do STF (Sarmento, 2015, p. 4).

Dessa forma, o STF assumindo essa pedagogia constitucional de respeito à supremacia da Carta da República permitirá que a promoção social ocorra nos espaços que Ihes são legítimos para que os sujeitos através de suas vidas politizadas no liame constitucional possam desenvolver seus projetos com fiel lastro democrático, porque se entendem como genuínos intérpretes do ordenamento podendo fundamentar suas interpretações questionadoras de acordo com a ordem jurídica maior. Tal fim é adquirido com a luta cívica, cidadã não articulada apenas por meio de processos judiciais, mas em conjunto com audiências, processos administrativos, formação de associações, instâncias que coordenem a autonomia pública e privada, a informação ética e não ética, que traga a população para o centro da representação.

\section{Apontamentos finais}

Com base nessa ideia, apresentou-se o julgamento da lei da Ficha Limpa ocorrido no STF, desenvolvendo posteriormente com base teórica na interpretação pluralista de Peter Häberle (2002) de modo a se constatar que nas sociedades complexas contemporâneas todos são intérpretes e devem participar não somente do processo de legitimação, mas em todos os espaços do Estado, inclusive nas decisões judiciais, contribuindo com suas realidades, superando-se a ideia de uma hermenêutica constitucional fechada a um seleto grupo de magistrados. Porém, resguardandoIhes a precípua função de defesa dos direitos fundamentais e dos excessos das maiorias, pois embora seja um tanto quanto radical a extensão do número de intérpretes, na teoria de Häberle há a preservação da relação texto-contexto, quer dizer, da normatividade da Constituição.

Na perspectiva de Hesse (2002), essa normatividade é ricamente defendida com o esforço de demonstrar que a essência da Constituição não deve ser confundida com vontade política, por isso é preciso que seja defendida pela jurisdição constitucional. Porém, para tanto requer uma hermenêutica que aproxime a sociedade, mas não desvirtue os limites do ordenamento jurídico. $\mathrm{Na}$ realidade, tudo isso aproxima substancialmente os sujeitos do Estado, este compreendido em todos os seus poderes, através do respeito à Constituição. A necessidade de se abordar essa temática através da categoria teórica da cidadania vem desse pressuposto, de que ela impulsiona a democracia, 
desta maneira é importante a participação de cada cidadão como intérprete para que possa legitimar os seus projetos democráticos e até mesmo as decisões judiciais.

O trabalho, portanto, não parte para a constatação de um fato, mas para a provocação de um ato de respeito ético ao constituinte originário, que é o povo, por parte de quem lhe deve a guarda maior, para que respaldados em sua atuação todos os indivíduos e instituições possam interpretar os seus direitos e deveres a partir dela, podendo mudar o final dessa história de desigualdade, de antagonismo social. Em razão disso que se entende o papel majoritário do STF como um problema democrático. Dessa forma, caminha-se na perspectiva de que a cidadania tem o condão de contribuir para a hermenêutica constitucional e, por conseguinte, é capaz de legitimar novas fontes do direito. Nesse caso, a atuação contramajoritária pode significar um remodelamento da própria cidadania, pois não adianta movimentar a esfera pública e cada ministro do STF resolver as lides conforme a sua consciência representacional. 


\section{REFERRÊNCIAS BIBLIOGRÁFICAS}

Abboud, G. (2012). STF vs Vontade da Maioria: as razões pelas quais a existência do STF somente se justifica se ele for contramajoritário. Revista dos Tribunais, São Paulo: RT.

Abboud, G. (2013). 25 anos da Constituição Federal: parabéns à Geni. Revista dos Tribunais, São Paulo, 45-52.

Abboud, G. (2016). Processo constitucional brasileiro. São Paulo: Editora Revista dos Tribunais.

Ação Direta de Inconstitucionalidade (ADI) 4277. (2011). Relator: Ministro Carlos Ayres Britto. Brasília, publicação: DJ 13.10.2011. Recuperado de [www.stf.gov.br]. Consultado [10-01-2018].

Ação Direta de Inconstitucionalidade (ADI) 4578. (2012). Rel.: Ministro Luiz Fux. Brasília, publicação: DJ 29.06.2012. Recuperado de [www.stf.gov.br]. Consultado [10-01-2018].

Alvim, J. L. R. (2006). O modelo de direito procedimentaldiscursivo em Jürgen Habermas. Confluências (Coimbra), Niterói, n 05, 42-55.

Amado, J. A. G. (2004). A sociedade e o direito na obra de Niklas Luhmann. Rio de Janeiro: Editora Lúmen Júris.

Arguição de descumprimento de preceito fundamental (ADPF) 54. (2011). Rel.: Ministro Marco Aurélio. Brasília, publicação: DJ 30.04.2013. Recuperado de [www.stf.gov.br]. Consultado [10-01-2108].

Barroso, L. R. \& Osório, A. (2016). "Sabe com que está falando?": Notas sobre o princípio da igualdade no Brasil contemporâneo. Revista Direito \& Práxis, 7, 204-232.

Barroso, L. R. (2009). Retrospectiva 2008. Judicialização, ativismo e legitimidade democrática. Revista Eletrônica de Direito do Estado (REDE), no 18, Salvador, Instituto Brasileiro de Direito Público. Recuperado de [http://www. direitodoestado.com.br/rede.asp]. Consultado [10-01-2018].

Barroso, L. R. (2015). A razão sem voto: o Supremo Tribunal Federal e o governo da maioria. Revista Brasileira de Políticas Públicas, 5, número especial, 23-50.

Barroso, L. R. (2016). Do Brasil que temos para o Brasil que queremos: Caminhos e sugestões para um país melhor. Jota. Brasília. Recuperado de [http://jota.uol.com.br/brasil-quetemos-para-o-brasil-que-queremos-caminhos-e-sugestoespara-um-pais-melhor]. Consultado [10-01-2018].

Basile, J. (2011). Código de Processo Civil está revolucionário. Valor Econômico. Recuperado de [http://www.valor. com.br/politica/997988/codigo-de-processo-civil-serarevolucionario]. Consultado [10-01-2018].

Benevides, M. V. M. (1994). Cidadania e democracia. Lua Nova, no 33, 5-16. Recuperado de [http://www.scielo.br/scielo. php?script=sci_arttext\&pid=S0102-64451994000200002]. Consultado [10-01-2018].

Buarque, C. (1977-1978). Folhetim. Recuperado de [http:// www.chicobuarque.com.br/letras/folhetim_77.htm]. Consultado [10-01-2018].
Código de Processo Civil. (2015). Lei no 13.105 de 16 de março de 2015. Recuperado de [http://www.planalto.gov.br/ ccivil_03/_ato2015-2018/2015/lei/l13105.htm]. Consultado [10-01-2018].

Constituição da República Federativa do Brasil de 1988. (1988). Brasília. Recuperado de [http://www.planalto.gov.br/ ccivil_03/Constituicao/Constituicao.htm]. Consultado [10-012018].

Dallari, D. A. (2007). O poder dos juízes (3a ed). São Paulo: Saraiva.

Falção, J. (2012). Peso da Vontade Popular está no Centro do Debate no STF: aprovação da lei da ficha limpa dá início a uma nova forma de democracia. Folha de São Paulo, Recuperado de [http://direitorio.fgv.br/noticia/aprovacao-da-lei-da-fichalimpa-da-inicio-a-nova-democracia]. Consultado [10-012018].

Garschagen, B. (2015). Pare de acreditar no governo: por que os brasileiros não confiam nos políticos e amam o Estado (7a ed). Rio de Janeiro: Record.

Häberle, P. (2002). Hermenêutica constitucional: a sociedade aberta dos intérpretes da constituição: contribuição para a interpretação pluralista e "procedimental" da constituição (G. F. Mendes, Trad.). Porto Alegre: Sergio Antonio Fabris Editor.

Habermas, J. (2012). Direito e Democracia: entre a facticidade e validade (vol. I e II, $2^{\text {a }}$ ed., F. B. Siebeneichler, Trad.). Rio de Janeiro: Tempo Brasileiro.

Hesse, K. (1991). A força normativa da Constituição (G. F. Mendes, Trad.) Porto Alegre: Sergio Antonio Fabris Editor.

Maciel, F. M., Alavim, J. L. R. \& FERREIRA, L. P. (2015). Papel contramajoritário do STF: impasse ao modelo de direito procedimental discursivo? (no prelo, vol. I.). $5^{\circ}$ seminário interdisciplinar em sociologia e direito - terceiro mundo terceirizado, Niterói: PPGSD.

Maus, I. (2000). Judiciário como superego da sociedade: o papel da atividade jurisprudencial na "sociedade órfã" (M. Lima \& P. Albuquerque, Trad.) Novos estudos - CEBRAP (58), 183-202.

Novelino, M. (2013). A influência da opinião pública no comportamento judicial dos membros do STF. M. Novelino \& A. Fellet. (Org.). Constitucionalismo e democracia (vol. 1, pp. 265-328). Salvador: Juspodivm.

Petição n. ${ }^{\circ}$ 3.388-4 / RO. (2009). Brasília. Rel.: Min. Carlos Britto. Brasília. Recuperado de [www.stf.gov.br]. Consultado [10-012018].

Presidentes da república que nomearam ministros para o supremo tribunal federal. (2016). Brasília. Recuperado de [http://www.stf.jus.br/portal/ministro/ministro. asp?periodo=stf\&tipo=quadro]. Consultado [10-01-2018].

Resolução n 175, de 14 de maio de 2013 do Conselho Nacional de Justiça (2013). Brasília. Recuperado de [http://www.cnj.jus. br/images/imprensa/resolu\%C3\%A7\%C3\%A3o_n_175.pdf]. Consultado [10-01-2018]. 
Ribeiro, D. C. S. (2015). Apontamentos sobre a Crítica Hermenêutica do Direito e a consolidação do pensamento constitucional. Quaestio luris (ano 8, n 4), Rio de Janeiro. Recuperado de [http://www.e-publicacoes.uerj.br/index. php/quaestioiuris/article/view/20952]. Consultado [10-01 2018].

Sarmento, D. (2016). O papel contramajoritário do STF. Recuperado de [http://www.tjrj.jus.br/ documents/10136/1186860/man-debat-des-luiz-fernandoribeiro-carvalho.pdf]. Consultado [10-01-2018].

Streck, L. (2015). Estado de Coisas Inconstitucional é uma nova forma de ativismo. Recuperado de [http://www.conjur. com.br/2015-out-24/observatorio-constitucional-estadocoisas-inconstitucional-forma-ativismo]. Consultado [10-012018].

Streck, L. (2014). Hermenêutica jurídica e(m) crise: uma exploração hermenêutica da construção do direito ( $11^{\mathrm{a}} \mathrm{ed}$ ). Porto Alegre: Livraria do Advogado.

Streck, L. (2016). Na ânsia de condenar, MPF usa inversão do ônus da prova no Supremo. Recuperado de [http:// www.conjur.com.br/2016-mai-26/senso-incomum-ansiacondenar-mpf-usa-inversao-onus-prova-stf]. Consultado [10-01-2018]

Streck, L. (2016). O rubicão e os quatros ovos do condor: de novo, o que é ativismo? Recuperado de [http://www.conjur. com.br/2016-jan-07/senso-incomum-rubicao-quatro-ovoscondor-ativismo]. Consultado [10-01-2018].

Streck, L. L, Barretto, V. P., Oliveira, R. T. (2009). Ulisses e o canto das sereias. Sobre ativismos judiciais e os perigos da instauração de um terceiro turno da constituinte. Jus Navigandi (ano 14, n०2218). Recuperado de [http://jus.com. br/artigos/13229]. Consultado [10-01-2018]. 